\title{
Environmental controls on growing-season sap flow density of Quercus serrata Thunb in a temperate deciduous forest of Korea
}

\author{
Nahida Laiju ${ }^{1}$, Dennis Otieno ${ }^{2}$, Eun-Young Jung ${ }^{2}$, Bora Lee ${ }^{2}$, John Tenhunen ${ }^{2}$, Jong-Hwan Lim ${ }^{3}$, \\ Joo-Han Sung ${ }^{3}$ and Sinkyu Kang ${ }^{1, *}$ \\ ${ }^{1}$ Department of Environmental Science, Kangwon National University, Chuncheon 200-701, Korea \\ ${ }^{2}$ Department of Plant Ecology, University of Bayreuth, Bayreuth 95440, Germany \\ ${ }^{3}$ Korea Forest Research Institute, Seoul 130-712, Korea
}

\begin{abstract}
Sap flux density (SFD) measurements were used, in combination with morphological characteristics of trees and forest structure, to calculate whole-tree transpiration, stand transpiration (St) and mean canopy stomatal conductance (Gs). Analysis based on the relationships between the morphological characteristics of trees and whole tree water use, and on the responses of SFD and Gs to short wave radiation (RR), vapor pressure deficit (VPD) and soil water content (SWC) during drought and non-drought periods were conducted. The results showed a strong positive correlation between whole tree transpiration and both tree diameter at breast height $(\mathrm{DBH})\left(r^{2}=0.95, P<0.05\right)$ and sapwood area (SA) $\left(r^{2}=0.98\right.$, $P<0.05)$. Relationships between SFD and DBH $\left(r^{2}=0.25\right)$, as well as SA $\left(r^{2}=0.17\right)$ were weak. Daily SFD of Quercus serrata Thunb was closely related to VPD and RR. Although operating at different time scales, RR and VPD were important interacting environmental controls of tree water use. SFD increased with increasing VPD $(<1 \mathrm{kPa})$ and RR. SWC had a considerable effect on stand transpiration during the drought period. The relationships between SFD, VPD and RR were distorted when SWC dropped below 35\%.
\end{abstract}

Key words: drought effect, sapflow, stand transpiration, Quercus serrata

\section{INTRODUCTION}

In East Asia, precipitation is concentrated in the short monsoon period between July and August, leaving the rest of the year mostly dry, and limiting the availability of water to trees since most of the soil water store is rapidly depleted (Shin 2002, Hwang et al. 2008). In South Korea, most forests are located in mountainous areas which experience rapid lateral water flux, as well as uneven distribution of soil water, further adding to the forest trees vulnerability to drought. In areas where precipitation exceeds potential evaporation, annual water use by trees equals cumulative transpiration, which depends on atmospheric conditions and their interactions with stomatal conductance, canopy architecture and leaf area (Landsberg and Gower 1997). When water in the rhizosphere is limiting, to the extent that root water uptake cannot cope with transpirational demands, then trees will respond by closing their stomata in order to limit the drop in tissue water potentials to dangerous levels that could cause cavitation of the conducting vessels (Sperry and Pockman 1993, Cochard et al. 1996).

Transpiration is a major contributor to water loss in forests (O'Grady et al. 2008), constituting a major hydrologic

\section{Open Access http://dx.doi.org/10.5141/JEFB.2012.026}

This is an Open Access article distributed under the terms of the Creative Commons Attribution Non-Commercial License (http://creativecommons org/licenses/by-nc/3.0/) which permits unrestricted non-commercial use distribution, and reproduction in any medium, provided the original work is properly cited.
Received 05 April 2012, Accepted 02 July 2012

*Corresponding Author

E-mail: kangsk@kangwon.ac.kr

Tel: +82-33-250-8578 
component of the montane-forested catchments, and its quantification is critical for water resource management. The accurate estimation of tree transpiration is however difficult, particularly in rugged mountainous terrain. The sap flow technique is a useful tool for investigating forest water use i.e., transpiration at temporal and spatial scales (Ford et al. 2007, Kumagai et al. 2007, Jung et al. 2011). In recent years, measurements of water use at the individual tree level have become more widespread, due to the development of reliable sap flow techniques (Granier 1985, Köstner et al. 1998, Dierick and Hölscher 2009). A common approach for estimating transpiration is based on the measurement of sap flux density (SFD) by the Thermal Dissipation Probe method (Granier 1987, Oren et al. 1998). The sap flow based canopy conductance (Gs) can provide a way of relating Gs to environmental factors, and help to explain the mechanism of water use of forest in different habitats. Sap flow measurements can distinguish transpiration among individuals and among class in the stand.

Understanding how transpiration varies according to climate factors as well as soil water content (SWC) is vital in forest hydrology studies. Variation in sap flow rates is explained on the basis of variation of different environmental controls, such as heterogeneity in soil water conditions, vapor pressure deficit (VPD), short wave radiation (RR) and also on the basis of methodological differences in sap flow measurements. Implications of temporal water shortage on temperate forest trees with respect to leaf water status (Hinckley et al. 1981), stomatal conductance, photosynthesis (Epron and Dreyer 1993) and hydraulic conductivity (Bréda et al. 1993, Cochard et al. 1996) have been studied extensively. It was shown that tree sap flow rates scaled to the stand level plus evapotranspiration from soil and the understory agreed with water vapor fluxes measured above the forest canopy with the eddycorrelation techniques (Granier et al. 1996, Köstner et al. 1998). In the course of a drought, gradually decreasing stomatal conductance, pre-dawn leaf water potential, assimilation and growth are commonly observed, accompanied by a stimulation of fine root growth (Leuzinger et al. 2005). With regard to water deficits, Scots pine closes stomata when the soil water deficit has reached a specific threshold (Irvine et al. 1998), whereas pubescent oak maintains high transpiration rates despite the incidence of drought (Nardini and Pitt 1999), partly due to an ability to extract water from deep soil layers and groundwater (Valentini et al. 1992).

An improved understanding of how environmental factors, particularly SWC, RR and VPD influence stand tran- spiration is necessary in order to predict how these temperate forests may respond to the predicted reductions in precipitation due to climate change. In this study, we examined how the regulation of transpiration in individual trees responded to changes in SWC. We selected the tree species, Quercus serrata, because it is widely distributed in lowland forested areas of the Korean Peninsula. We hypothesized that there exists a SWC threshold, which determines critical SFD values under conditions of limited soil water supply. The main objectives of this study were 1) to relate the variability in sap flow to environmental variables; 2) to determine daily and seasonal patterns of stand transpiration, and 3) to investigate how drought affects tree sap flow, and stand transpiration.

\section{METERIALS AND METHODS}

\section{Study site}

The study site was at Gwangneung Experimental Forest (GN) located in central western part of the Korean Peninsula $\left(37^{\circ} 44^{\prime} \mathrm{N}\right.$ and $\left.127^{\circ} 9^{\prime} \mathrm{E}\right)$, and the elevation of the site is $330 \mathrm{~m}$ above sea level. The Korean peninsula is located on the boundary between polar and tropical climates, and is strongly influenced by a continental air mass. During winter, strong continental high-pressure systems develop over Siberia, bringing dry cold air to Korea. In summer, monsoon brings southerly winds and abundant moisture from the ocean. Precipitation is concentrated in summer period, with $45-60 \%$ of the total annual rainfall occurring in summer, and $3-10 \%$ in winter.

A flux tower was constructed at the site in order to monitor changes in carbon/energy fluxes within the microclimate since 2001 (Lee et al. 2007). The density of the trees was $1,473 /$ ha with a total biomass of 261 ton/ha, while the basal area was $28 \mathrm{~m}^{2} / \mathrm{ha}$. The site was dominated by Quercus serrata (51\% of total basal area), followed by Carpinus laxiflora (23\% of total basal area). Quercus serrata is the most common tree species in Korea. Based on tree location, size, and stem structure, 6 trees of Quercus serrata, were chosen for sap flow measurements. Our strategy was to measure sap flow in trees with a range of diameter at breast heights (DBHs), so as to ensure that the entire stand was represented. In the study year 2007, the growing season for deciduous trees lasted from the beginning of April (bud break) to the beginning of November. The measurements were started in May 2007 and continued till November, 2007. 


\section{Micrometeorology}

Precipitation (Rain gauge; Pluvio, OTT, Messtechnik, Germany), air temperature and relative humidity at $40 \mathrm{~m}$ and $20 \mathrm{~m}$ height (CSAT3; Campbell Sci, Logan, UT, USA and L17500; Li-Cor, Lincoln, NE, USA, respectively), The depth at which SWC determinations were carried out averaged between 0-0.3 m (CS615; Campbell Sci), radiation (CNRI; Kipp \& Zonen, Delft, Netherlands) was recorded at a weather station constructed on the GN experimental forest site. Data were recorded every $5 \mathrm{~min}$, averaged and logged every $30 \mathrm{~min}$ using a CSAT3 Campbell data logger (Campbell Scientific, Logan, UT, USA) (Lee et al. 2007). As $\mathrm{GN}$ is mountainous and located within the base of bedrock, the rooting depths as well as the depth of the effective soil layer were assumed to be $0.3 \mathrm{~m}$. To investigate the drought effect, we postulated that SWC is responsible for the variation of SFD in Q. serrata. Barring VPD, all meteorological data from the tower were obtained online (www. asiaflux.net). VPD was calculated from temperature and humidity by using the equation suggested by Murray (1967).

$$
\mathrm{VPD}=\mathrm{ae} \mathrm{e}^{[\mathrm{bT} / \mathrm{T}+\mathrm{c}]}(1-\mathrm{RH})
$$

where, a, b and c are $0.611 \mathrm{kPa}, 17.502$ and 240.97 respectively.

\section{Sap flow measurements}

Sap flux density within the active xylem (SFD) was measured continuously between April and November 2007 using the constant current supply method (Thermal Dissipation Probe) described by Granier (1985, 1987). Each sensor consisted of two, $20 \mathrm{~mm}$ long probes (2 mm in diameter), each equipped with a copper constantan thermocouple and wrapped with heating wire (Jung et al. 2011). The two probes for each sensor were inserted radially into the xylem, separated vertically by a $10-15 \mathrm{~cm}$ gap. One sensor was inserted into each selected tree at a depth of 0-20 mm. The upper probe was continuously heated at a constant power $(0.2 \mathrm{~W})$ and the lower one was kept at trunk temperature (reference probe). The heat was dissipated into the sapwood and transported by the vertical sap flux surrounding the probe. The temperature difference between the upper heated probe and lower unheated reference probe was measured and converted into SFD according to Granier (1987). During conditions of zero sap flow, e.g., at night when VPD was zero or near zero, and during prolonged rain events, the temperature differ- ence $\Delta \mathrm{T}$, between the probes reaches a maximum, which is then used as reference for maximum $\Delta \mathrm{T}$. Sap flow during the day causes a decrease in temperature difference $\Delta \mathrm{T}$ by cooling the upper probe. This difference is used to calculate real time SFD.

The probes were inserted in the north-facing side of the stem, and covered with Styrofoam and reflective aluminum insulation to avoid the influence of natural temperature gradients originating from direct heat from the sun, and also to protect them from rainfall. Power was supplied from a $12 \mathrm{~V}$ battery that was constantly charged, via a charge controller, by solar panels installed on the tower above the tree canopy. Data were recorded every $30 \mathrm{~s}$ and averaged every $30 \mathrm{~min}$ with a data logger (DL2; Delta-T Devices, Cambridge, UK). A total of six trees were monitored from 27th April to 5 November 2007, a period that covered bud break to complete senescence.

Sap flow was calculated by multiplying SFD by sapwood area (SA). We cored trees in order to estimate the SA of the studied trees. Distinct color differences were used to identify the boundary between sapwood and heartwood. We established significant $\left(r^{2}=0.95\right)$ correlation between DBH and SA, described by the equation as already shown by Vertessy et al. (1995) and Wullschleger et al. (2001).

$$
\mathrm{SA}=\mathrm{B}_{0} \cdot \mathrm{DBH}^{\mathrm{B} 1}
$$

where SA is the sapwood area $\left(\mathrm{cm}^{2}\right), \mathrm{DBH}$ is the measured tree diameter at breast height $(\mathrm{cm})$, and $\mathrm{B}_{0}$ and $\mathrm{B}_{1}$ are species-specific coefficients, as determined with regression techniques. In cases where more than one sensor was employed in one tree, sap flux was integrated over the entire sapwood by averaging the respective fluxes in the different sapwood depths.

Plot SAs for all trees within the plot were estimated according to Eq. (2) and the estimates were then used to calculate the total sap flow. SFD within the xylem was calculated from an empirical relationship validated for several species by Granier (1985) and recently revalidated by Clearwater et al. (1999).

$$
S F D=119 \cdot k^{1.231}
$$

where SFD is sap flux density $(\mathrm{mm} / \mathrm{s})$ and $k$ is related to $\Delta \mathrm{T}$ of the two probes

$$
k=\frac{\Delta T_{o}-\Delta T}{\Delta T}
$$

where $\Delta \mathrm{T}_{0}$ is the value of $\Delta \mathrm{T}$ when there is no sap flux. This model is widely used as standard calibration. 
Despite the robustness of the sap flow technique, scaling procedures are required to extrapolate stand level estimates from SFD measurements of individual trees. Transpiration is scaled up to the stand level using the following equation (Granier et al. 1996, Wilson et al. 2001, Wullschleger et al. 2001, Pataki and Oren 2003).

$$
S t=\frac{J_{s} \cdot A_{S_{-} \text {stand }}}{A_{G}}
$$

where St is stand transpiration, $\mathrm{J}_{\mathrm{s}}$ the mean stand SFD, $\mathrm{A}_{\mathrm{S}_{-} \text {stand }}$ the stand sapwood area, and $\mathrm{A}_{\mathrm{G}}$ is the ground area. Conventionally, $A_{S_{-} \text {stand }}$ is estimated by integrating all the individual tree sapwood area $\left(\mathrm{A}_{\mathrm{S}_{-} \text {tree }}\right)$ estimates in the stand. Species-specific allometric equations describing the relationships between stem diameter $(\mathrm{DBH})$ and $\mathrm{A}_{\mathrm{S}_{\text {trree }}}$ are used for this purpose (Vertessy et al. 1995, Cienciala et al. 2000, Roberts et al. 2001, Wullschleger et al. 2001). Estimates of stand transpiration derived through extrapolation of species-specific xylem sap flow rates can only be as good as the original measurements.

The mean canopy stomatal conductance was calculated by using equation (Köstner et al. 1992, Granier and Bréda 1996, Pataki et al. 1998)

$$
G s=\frac{S t}{A_{G} \cdot L A I \cdot 18} \times \frac{\rho \cdot G v \cdot(T+273)}{V P D}
$$

where St is the stand transpiration $\left(\mathrm{J}_{\mathrm{s}} \cdot \mathrm{SA}\right), \mathrm{A}_{\mathrm{G}}=$ stand area, $\mathrm{LAI}=$ leaf area index of stand, $\rho=$ the water specific density, $\mathrm{T}=$ the air temperature, $\mathrm{Gv}=$ the gas constant, $\mathrm{VPD}=$ the vapor pressure deficit.

Leaf area index (LAI) is the amount of leaf area in a vegetation canopy per unit land area, and was measured by indirect methods using the Li-Cor LAI 2000 plant canopy analyzer. Estimated SFD and canopy stomatal conductance were correlated with climatic factors such as VPD, RR and SWC. All statistical analyses were performed with Sigma Plot 9.01 and Sigmastat 3.11 program (Systat Software Inc., San Jose, USA).

\section{RESULTS}

\section{Microclimate and soil moisture}

The annual mean air temperature at the study site was $11.3^{\circ} \mathrm{C}$ while annual precipitation was $1,365 \mathrm{~mm}$. The mean daily air temperature from May to November in 2007 was $21.2^{\circ} \mathrm{C}$. During 2007, rainfall was well distributed over the growing season, although rainfall in July and August was heavier. The total precipitation was $933 \mathrm{~mm}$
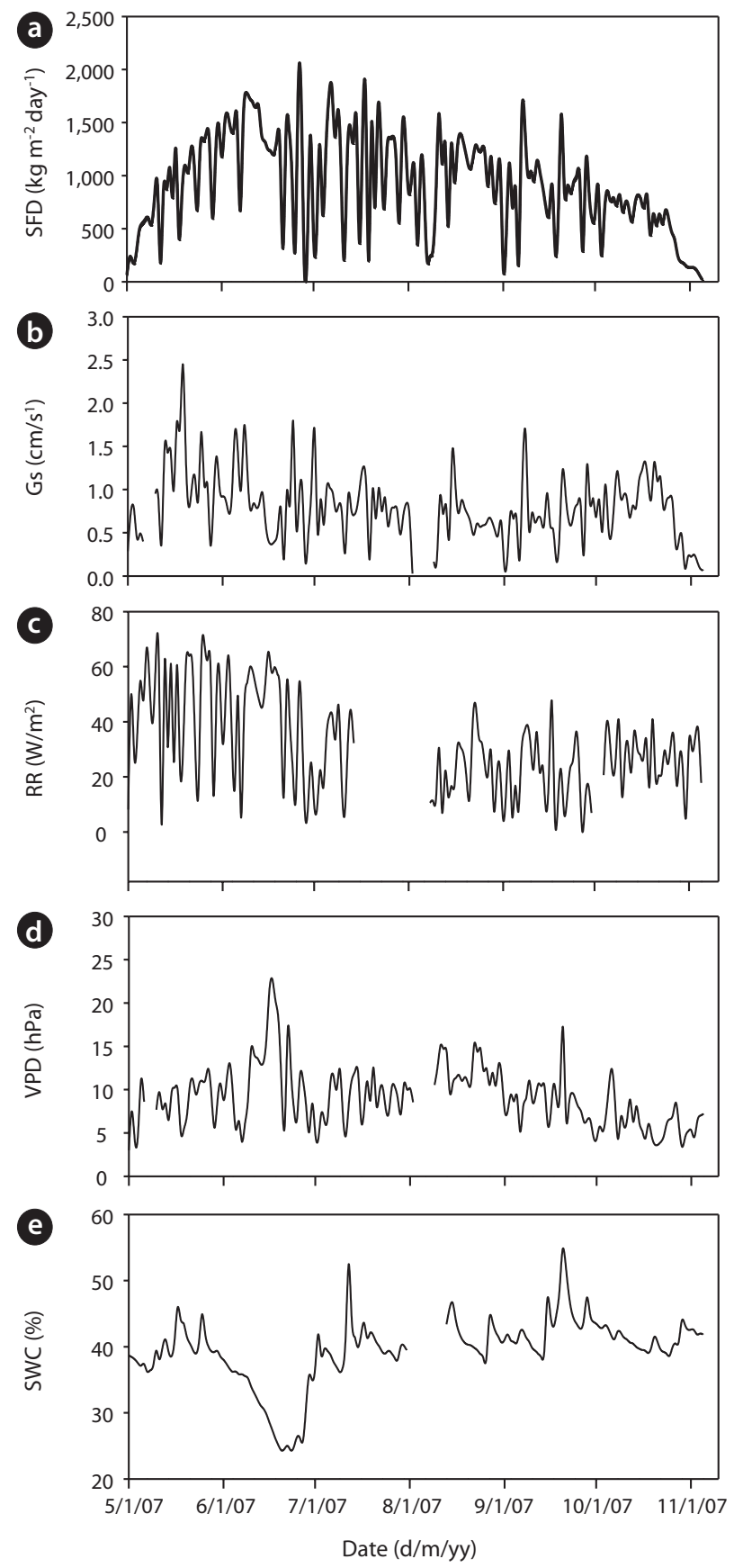

Fig. 1. Seasonal pattern of (a) sap flux density (SFD) and (b) canopy stomatal conductance (Gs) of Quercus serrata in response to (c) short wave radiation (RR), (d) vapor pressure deficit (VPD) and (e) soil water content (SWC).

from May to November. Early June was the driest, while August was the wettest period during the study. Although a SWC of less than $30 \%$ is considered, in general, as drought condition in Gwangneung soils, we considered the drought condition to occur when SWC dropped below $35 \%$, and this condition was observed throughout most of the month of June, and was much more pronounced 
towards the end of the month (Fig. 1e). SWC in the upper $0.3 \mathrm{~m}$ varied over the measurement period. During the drought, SWC in the upper $0.3 \mathrm{~m}$ soil declined to $24 \%$ in June, while the maximum SWC (55\%) was observed during the month of September. VPD showed seasonal variations, with the highest values occurring on June 17 (Fig. 1d). Daily mean VPD during drought and non-drought periods were $13.64 \mathrm{hPa}$ and $8.58 \mathrm{hPa}$, respectively, while the respective maximum values were $22.68 \mathrm{hPa}$ and 17.27 $\mathrm{hPa}$. The recorded maximum daily average value of radiation was $68.47 \mathrm{~W} / \mathrm{m}^{2}$ with an average of $31.18 \mathrm{~W} / \mathrm{m}^{2}$ during the study period (Fig. 1c).

\section{Plant characteristics}

Table 1 shows the morphological characteristics of the selected Q. serrata trees for sap flow measurements and their average SFDs (30 min data per day throughout the study period) and tree water use. As SFD is related to DBH, tree height, sapwood depth and SA (Sevanto et al. 2008, Liu et al. 2008), we also determined the coefficients between SFD with DBH, tree height, sapwood depth and SA from Table 1, where the statistically insignificant $\mathrm{r}^{2}$ values were determined with $0.26,0.32,0.26$, and 0.17 , respectively. The coefficients of determination between tree water use with DBH $\left(r^{2}=0.95\right)$, sapwood depth $(0.95)$, and SA (0.98) were statistically significant, though that for tree height (0.26) was not.

\section{Tree sap flux}

Results of seasonal SFD are shown in Fig. 1a. The maximum daily average SFD was $1,833 \mathrm{~kg} \mathrm{~m}^{-2}$ day $^{1}$. Temporal variation of SFD in response to RR and VPD were pronounced during the study period (Fig. 2). Diurnal patterns of SFD showed a steep morning increase, leading to maximum rates at around midday when RR or VPD was at its maximum, followed by a gradual decrease later in the afternoon during clear-sky day conditions (Fig. 2). The half-hourly measured SFD increased with VPD and RR during the study period, while the daily maximum or total SFD did not always increase with VPD and RR. In spite of higher RR and VPD, daily maximum or total SFD during the drought period (June 19-21) (Fig. 2) was less than that in the non-drought period (June 9-10 and July 6-7) (Fig. 2).

Fig. 3 shows the curvi-linear relationship between daily SFD and RR when SWC was above $35 \%\left(r^{2}=0.23\right)$, and also when SWC was lower than $35 \%\left(r^{2}=0.74\right)$. Similar relationships were observed between daily SFD and VPD when SWC was above $35 \%\left(r^{2}=0.41\right)$ and also below $35 \%$ $\left(r^{2}=0.36\right)$. SFD increased with increasing RR until a stable point was reached. Above RR stable point, SFD was controlled by VPD, when soil moisture was adequate. VPD therefore dominated over RR as a regulatory factor for tree responses. Below a critical SWC, SFD did not increase with increasing RR and VPD, but rather it decreased i.e., the abnormal patterns of SFD were observed in response to RR and VPD (Fig. 4). Although SWCs above 35\% had no significant influence on SFD responses to daily RR and VPD in the species, low SWC below $35 \%$ altered the sensitivity of SFD to RR and VPD (data not shown). This soil water effect is reflected in daily SFD responses to RR and VPD which are shown in both low and high SWCs in Fig. 2. SFD decreased with increasing RR and VPD (Fig. 5). The daily SFD at high VPD was significantly lower at low SWC. However, changes in half-hourly SFDs were not always in line with changes in VPD. SFD values reached a maximum of 1,833 $\mathrm{kg} \mathrm{m}^{-2}$ day $^{1}$ while the average VPD of that day was about $11.51 \mathrm{hPa}$. The SFD values changed little when VPD was higher than this value, which is possibly the upper VPD threshold. This suggested that high levels of VPD might limit water use. Above $35 \%$ SWC, the influence of VPD was higher than that of RR. But below

Table 1. Characteristics of Quercus serrata trees (QS) chosen for the measurement of tree water use

\begin{tabular}{ccccccc}
\hline Trees & $\begin{array}{c}\text { SA } \\
\left(\mathbf{c m}^{2}\right)\end{array}$ & $\begin{array}{c}\text { DBH } \\
(\mathbf{c m})\end{array}$ & $\begin{array}{c}\text { Height } \\
(\mathbf{m})\end{array}$ & $\begin{array}{c}\text { Sapwood depth } \\
(\mathbf{m m})\end{array}$ & $\begin{array}{c}\text { Average SFD } \\
\left(\mathbf{g ~ m}^{-2} \mathbf{s}^{-1}\right)\end{array}$ & $\begin{array}{c}\text { Tree water use } \\
(\mathbf{g} / \mathbf{s})\end{array}$ \\
\hline QS1 & 754.26 & 59.7 & 16 & 19.52 & 5.69 & 0.43 \\
QS2 & 277.44 & 36.3 & 15 & 18.61 & 5.31 & 0.15 \\
QS3 & 761.9 & 60 & 17 & 19.53 & 5.25 & 0.4 \\
QS4 & 177.89 & 29.1 & 12 & 18.33 & 4.42 & 0.08 \\
QS5 & 69.25 & 18.2 & 17 & 17.9 & 9.57 & 0.07 \\
QS6 & 556.07 & 51.3 & 17 & 19.19 & 6.08 & 0.34 \\
\hline
\end{tabular}

SA, sapwood area; $\mathrm{DBH}$, diameter at breast height; SFD, sap flux density. 
35\% SWC, increased VPD was found to reduce SFD. This might be the cause why the $r^{2}$ between VPD and SFD was lower than anticipated. Increasingly, the VPD effect was dominant over that of RR during the drought period even though the $r^{2}$ between RR and SFD was higher $\left(r^{2}=0.74\right)$.

To evaluate the effect of drought, we calculated the co- efficient of determination between SFD and SWC during the drought and non-drought periods. The relationship between SFD and SWC during the drought period was relatively strong $\left(r^{2}=0.12\right)$ compared to the non-drought period (Fig. 6). But this relationship was stronger during sunny days $\left(r^{2}=0.25\right)$ during the drought period. Maxi-
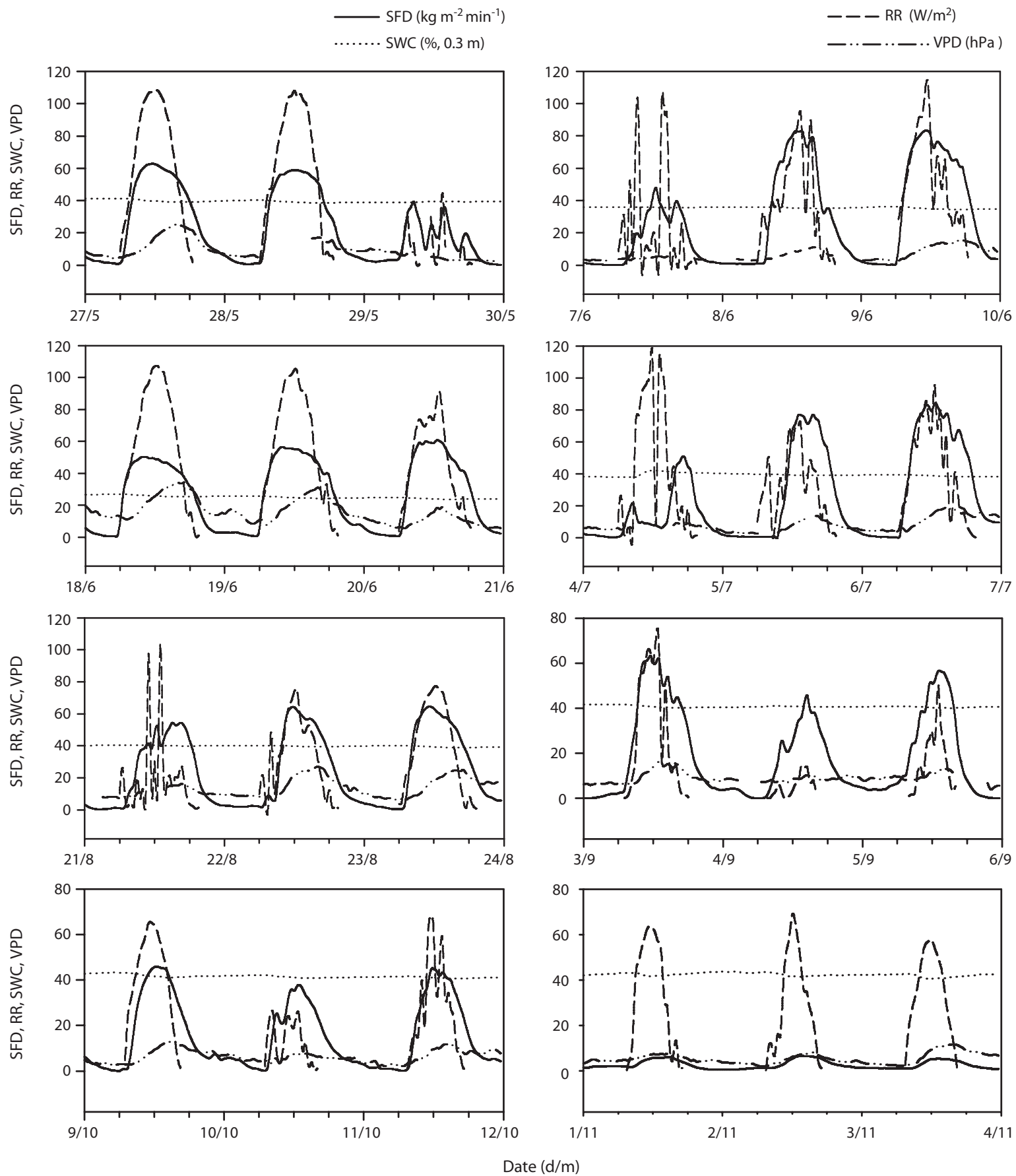

Fig. 2. Temporal variation of sap flux density (SFD) in response to short wave radiation (RR) and vapor pressure deficit (VPD) at approximate constant soil water content (SWC) measured at $0.3 \mathrm{~m}$ in Quercus serrata at Gwangneung in 2007. 
a
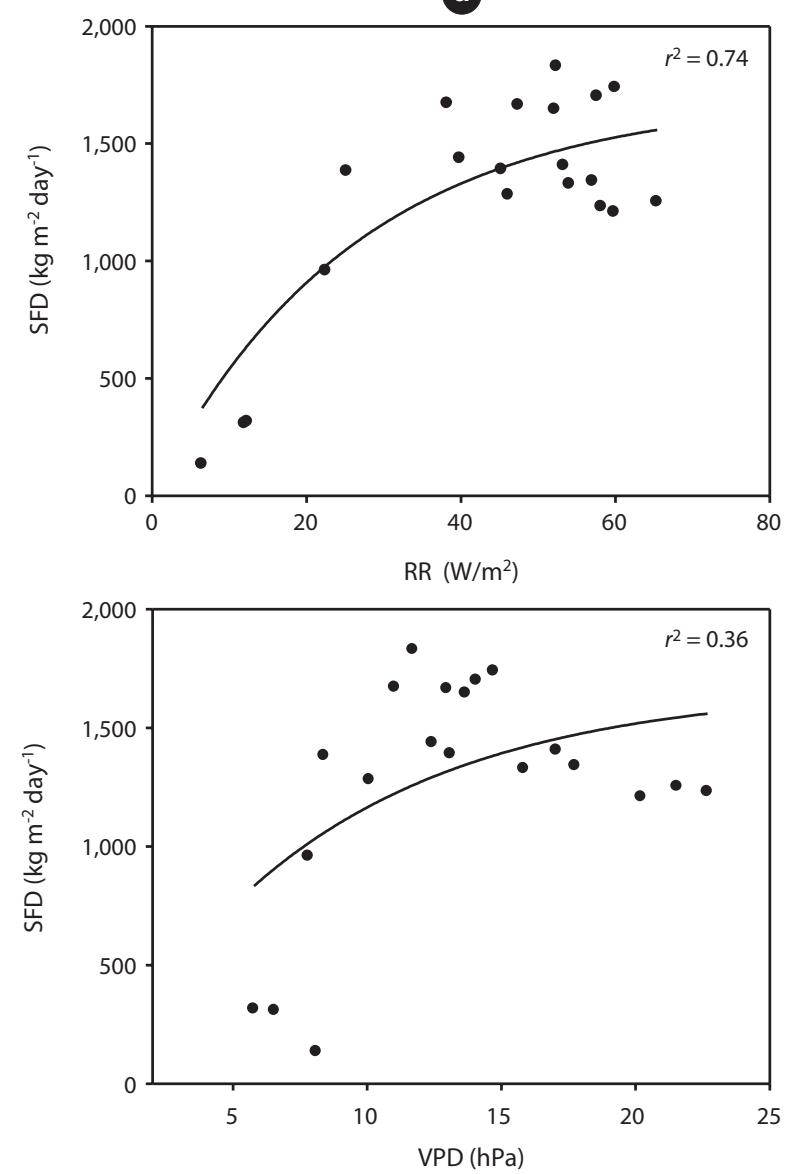

b

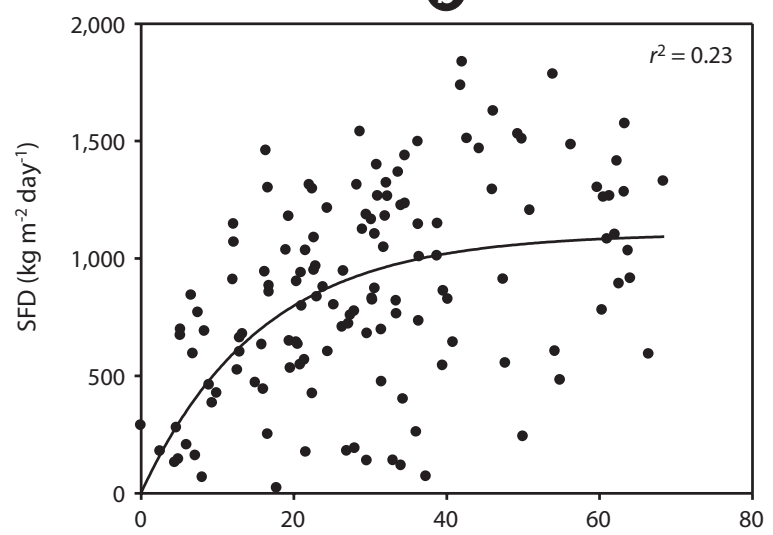

$\mathrm{RR}\left(\mathrm{W} / \mathrm{m}^{2}\right)$

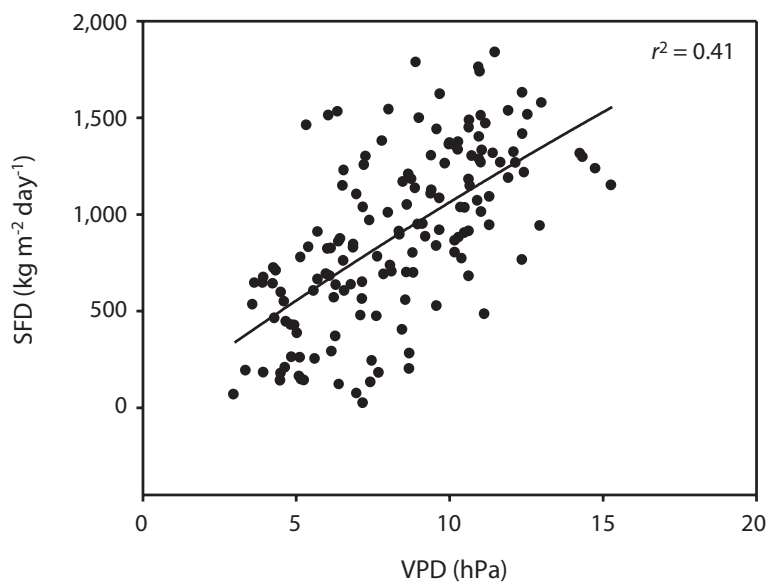

Fig. 3. Correlation between sap flux density (SFD) with short wave radiation (RR) and vapor pressure deficit (VPD) at (a) below $35 \%$ soil water content (SWC) and (b) above $35 \%$ SWC during the study period.

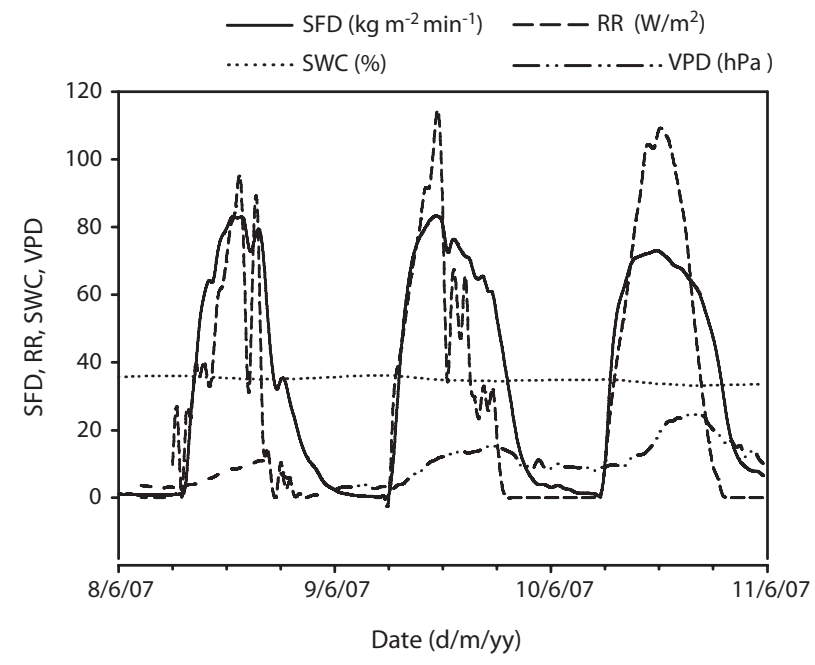

Fig. 4. Soil water content (SWC, \%) measured at $0.3 \mathrm{~m}$ at which sap flux density (SFD) shows abnormality with climatic factors and SWC. RR, short wave radiation; VPD, vapor pressure deficit.

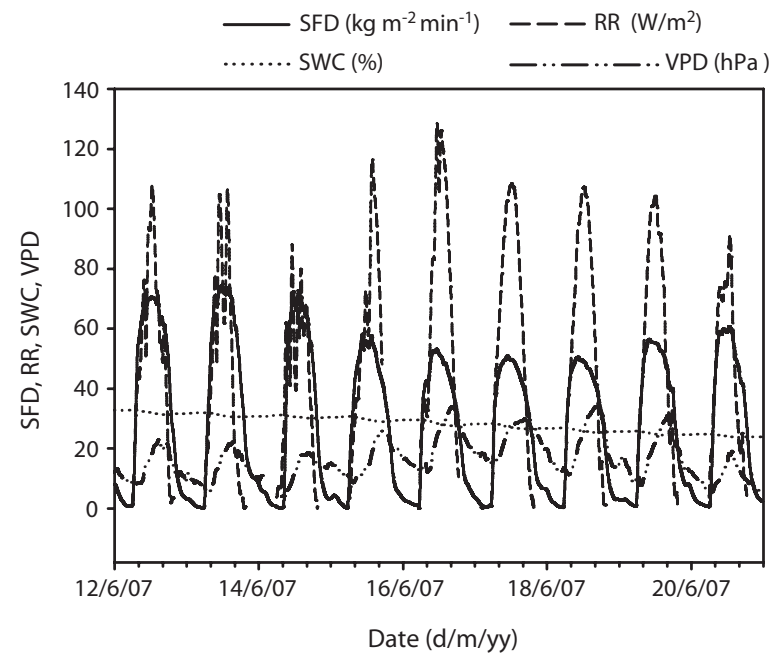

Fig. 5. Abnormal patterns of sap flux density (SFD) with climate and soil factors during drought period. RR, short wave radiation; SWC, soil water content; VPD, vapor pressure deficit. 

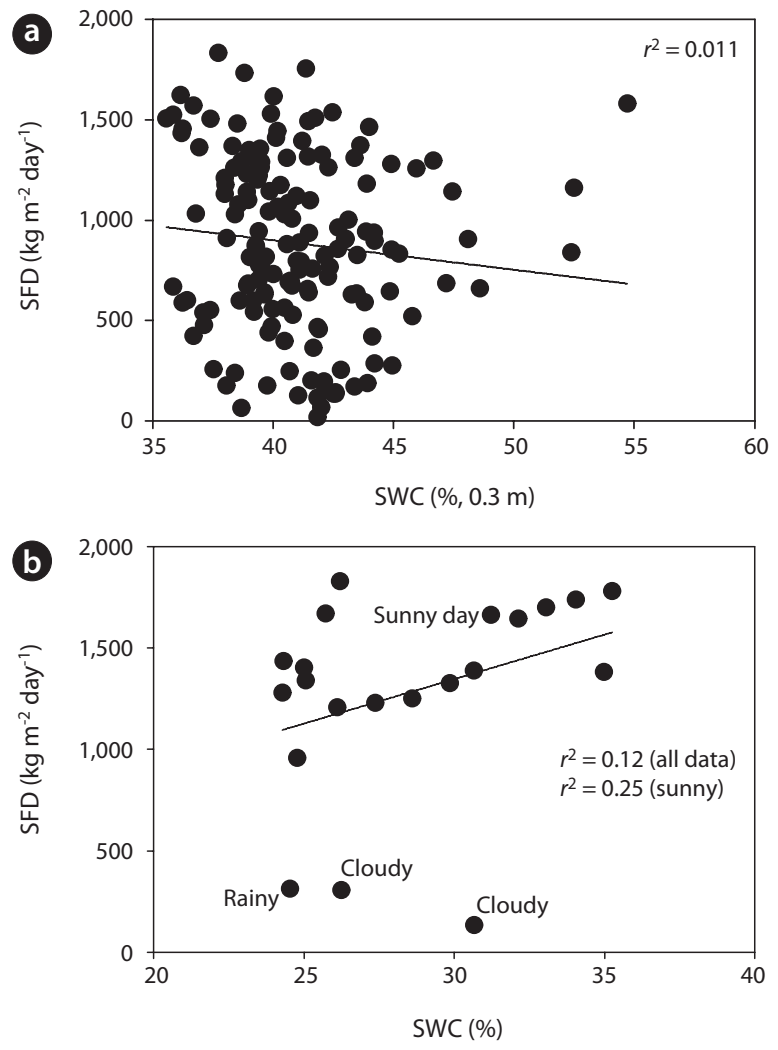

Fig. 6 . Correlation between sap flux density (SFD) and soil water content (SWC) measured at $0.3 \mathrm{~m}$ during (a) non-drought period and (b) drought period.

mum daily average Gs $(2.45 \mathrm{~cm} / \mathrm{s})$ occurred during the end of May (May 19) and Gs declined during drought (Fig. 1b). For example, measurements of Gs in June (on June 20 SWC was $24 \%$ ) at the peak of the drought were on average equal to $0.78 \mathrm{~cm} / \mathrm{s}$, which was $32 \%$ of the maximum Gs measured on May 19. In a shorter temporal scale, the response of Gs was mainly influenced by radiation and VPD (see Fig. 1b vs. Fig. 1c and 1d). Nevertheless, the long-term (e.g., seasonal) response was mainly controlled by soil moisture conditions (see Fig. 1b vs. Fig. 1e). Fig. 7 showes the relationship between Gs and VPD during drought and non-drought periods. A flat or negative slope indicates stomatal closure (Bovard et al. 2005) when VPD was high and SWC low. Before drought, the highest Gs value was $2.45 \mathrm{~cm} / \mathrm{s}$ while the highest value after drought was 1.70 $\mathrm{cm} / \mathrm{s}$. The relationship between Gs and VPD was negative during drought and generally positively strong $\left(r^{2}=0.72\right)$ during the period when SWC was high.

\section{DISCUSSION}

We found evidence that SWCs greater than $35 \%$ at 0.3 $m$ depth has no significant influence on the SFD of Q. serrata trees. The dominant controls on SFD were daily RR and VPD (Fig. 2). SWC influenced how SFD responded to changes in RR and VPD during the drought period (SWC $<35 \%$ ) (Fig. 5). Oren and Pataki (2001) observed similar magnitudes of sap flux rates in an oak-hickory forest under comparable VPD levels. Drought, viewed as a shortage in precipitation, is often coupled with high evaporative demand, which reduces moisture availability in a way that will negatively affect the normal functioning of trees (Pereira et al. 2006). Low soil water availability was found to be associated with a decline in SFD within this study (Fig. 6). SWC fluctuates according to its water supply from rainfall and drying after rainfall during the growing season. The root distribution profile of plants is an important character for water uptake when the vertical distribution of SWC is heterogeneous. Since SFD increased even after a minor rain event, it was assumed that Q. serrata has a significant amount of fine roots distributed within the shallow soil layers, which facilitate rapid water uptake after rain events. Considering the large crown size of these trees, they must also require good anchorage in the soil to stay erect and to withstand the frequent storms in this region. Thus, we concluded that $Q$. serrata has its roots distributed across a wide soil profile, which makes it well adapted to withstand drought and to take advantage of rain showers that don't penetrate deep soil layers as well as soil nutrients that are concentrated within the shallow soils.

Previous results illustrating the effect of SWC on transpiration and stomatal conductance have been presented by Tan et al. (1978), who measured the stomatal resistance $\left(r_{s}=1 / G_{s}\right)$ of a douglas fir stand over a period of one month, during summer when there was no rain. They showed that the effects of VPD were enhanced by dry soil. Kelliher et al. (1995) reported that even the moderately wet soil has a considerable effect on stomata, and hence, on transpiration rates. In this study, a good relationship was observed between SFD and stomatal behavior where $r^{2}=0.60$. Stomatal regulation of transpiration provides plants with some control over the development of water potentials sufficient to induce cavitation (Sperry et al. 2002). As water stress develops, stomatal closure progressively restricts transpiration and lowers the rate of decline in plant water potential.

During the drought period, stand transpiration and SFD declined with increasing VPD and RR. We observed significant differences in SFD responses to changing VPD above $1 \mathrm{kPa}$, at both high and low SWCs. When SWC was low, the trees showed declining Gs as VPD increased, as 
a
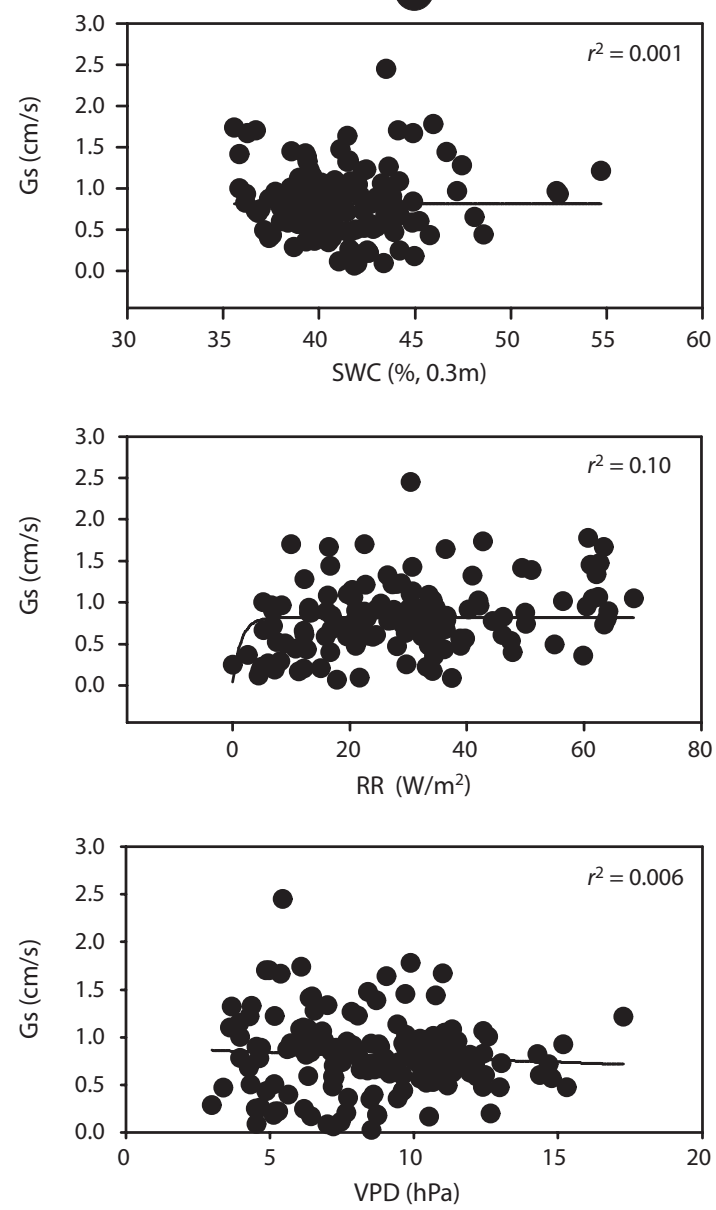

b
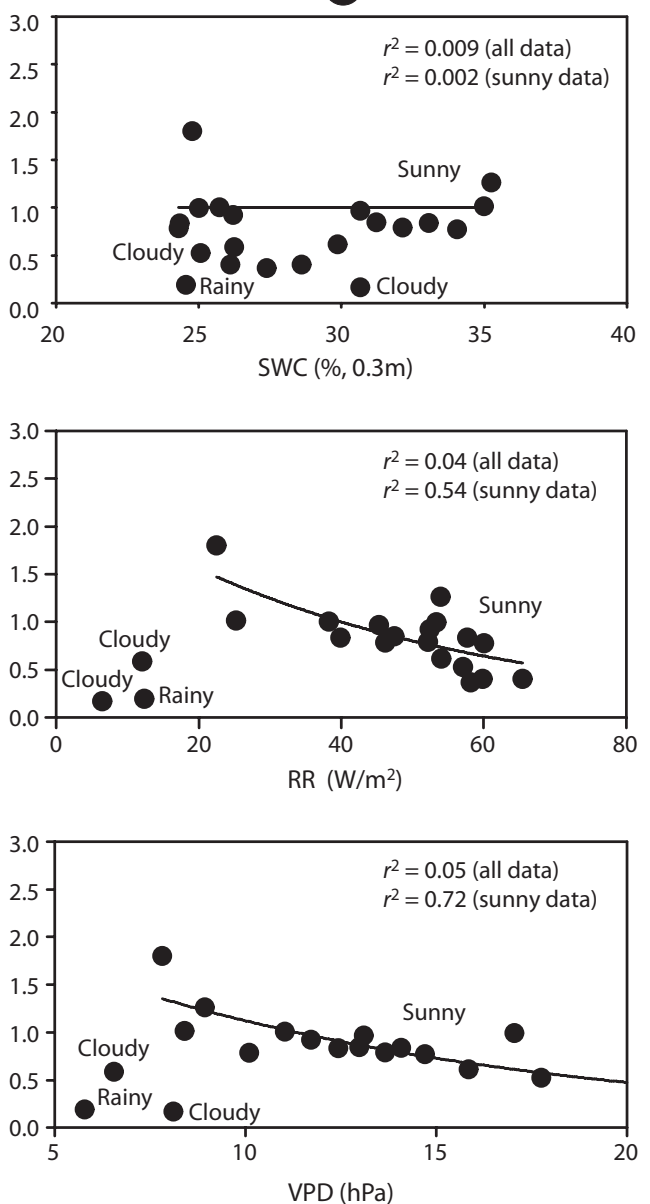

Fig. 7. Correlation between canopy stomatal conductance (Gs) and climatic factors and soil water content (SWC) measured at $0.3 \mathrm{~m}$ during the (a) nondrought period and (b) drought period. RR, short wave radiation; VPD, vapor pressure deficit.

opposed to the periods when SWC was high. Below 35 $\%$ of SWC there was a relatively strong relationship between SFD and SWC, with $r^{2}=0.08$, while $r^{2}$ for the relationship between SWC and SFD at SWC > 35\% was only 0.02 and was not significant. This implies that low SWC has the greatest effect on SFD. However, even if there is an adequate water supply, the conducting vessels have a limited capacity, and at some stage the stomata must react by either decreasing or holding Gs constant. In general, we found that SFD increased with increasing VPD less than $1 \mathrm{kPa}$. This response was independent of SWC during the non-drought period. At VPD $>1 \mathrm{kPa}$, however, SFD reached an asymptote as has been reported for other forest ecosystems (Meinzer et al. 1993, Goulden and Field 1994, Granier et al. 1996, Hogg et al. 1997, Oren and Pataki 2001). The response of SFD to VPD above $1 \mathrm{kPa}$ should reflect changes in leaf-level Gs (Hogg et al. 1997).

Transpiration rates vary with weather conditions and soil moisture (Wang et al. 2005). The first source of variation is due to weather, because available energy and atmospheric deficit in vapor pressure drive the transpiration flux from vegetation to the atmosphere (Granier et al. 2000). The second source is the biological regulation exerted through canopy stomatal conductance. We investigated the possible causes of differences in transpiration during drought. Lower transpiration rates should reduce the drought effect, maintaining water potentials at a safe margins above critical values that could lead to cavitation. An optimization procedure was used to establish the values of Gs in the Penman-Monteith equation, giving the closest agreement with measured values of SFD, indicating that Gs was a function of VPD, but dependent, at least to some degree, on SWC.

Several studies have reported the negative effect of soil water depletion on canopy conductance. Variation of Gs can be related either to soil water reserves or soil water 
deficits (Granier and Loustau 1994), or to the relative extractable water in the soil (Granier and Bréda 1996). Gs were found to progressively decrease when SWC varied from 35 to $24 \%$ (Fig. $7 \mathrm{~b}$ ), this decrease being more pronounced when SWC dropped below $35 \%$. Gs ranged from 0.03 to $2.45 \mathrm{~cm} / \mathrm{s}$. Canopy conductance declined in response to increasing VPD during drought, and the magnitude of reduction varied over the measurement period (Fig. 7b). However, after 4 pm, Gs did not increase in response to decreasing VPD due to declining light intensities. Variation in stomatal conductance is solely based on variability in RR and VPD (Cienciala and Lindroth 1995, Granier and Bréda 1996), and transpiration (Mott and Parkhurst 1991, Monteith 1995), which correlates with bulk plant water potential (Jarvis 1976, Hinckley et al. 1978). To address the primary objective of this study, it was necessary to relate Gs to RR, SWC and VPD. An empirical relationship between Gs and RR provides a convenient approach to describing the response of stomatal conductance to varying atmospheric conditions (Jarvis 1976, Sandford and Jarvis 1986, Whitehead 1998) (Fig. 7b).

The limitation to water use appeared to be due to major contributions of canopy or meteorological factors, as well as SWC. Stomatal conductance was positively related to bulk SWC, which is compatible with the hypothesis of hydraulic feedbacks (Garnier and Berger 1987). The surprisingly low sap flow rates at high VPD $(22.68 \mathrm{hPa})$ were a consequence of hot conditions in June where predawn temperatures remained well above $25^{\circ} \mathrm{C}$, and relative humidity was as low as $27 \%$. Therefore, stomata will close when the plant cannot sustain the rate of water loss driven by VPD. This suggests that all the empirical relationships established between Gs and VPD must have been influenced by the capacity of the soil-plant hydraulic conducting system. The relative insensitivity of SFD to high VPD could involve many changes related to transpiration, such as temperature (Idso et al. 1987), the water potential of foliage (Kellomäki and Wang 1996), xylem hydraulic resistance (Sperry and Pockman 1993) and water uptake of root systems (Kellomäki and Wang 2001). Early measurements of the foliage of Scots pine indicated that temperature elevation significantly reduced the sensitivity of stomatal conductance to decreasing foliage water potential under short-term water stress conditions (Kellomäki and Wang 1996), and to increasing VPD (Kellomäki and Wang 1997). It has been suggested that a feedforward response to soil drying involves the transport of a chemical message (abscisic acid) from roots to foliage, causing reduced stomatal conductance independent of leaf water potential (Wartinger et al. 1990, Tardieu et al. 1992).
In considering the influence on stomatal conductance, and hence transpiration, we have to note that there is strong evidence that the effect of leaf water status can be overridden, and certainly modified, by chemical signals from the roots, or by changes in the conductance of the hydraulic pathways (Landsberg and Gower 1997). The shorter term relationship between transpiration and soil moisture is not a suitable tool for this purpose either, because the formal statistical dependence reflects the fact that the soil is usually moist during rainy days, when transpiration is low as a result of low solar radiation/VPD which determines the energy available for evaporation from the forest stand. While SWC is not a good measure of available soil water, it is a very good indicator of the same, and has been used over ages to show drought and its influence.

\section{CONCLUSION}

At different timescales, RR, VPD and SWC are important interacting environmental controls in the water flux of a temperate deciduous forest ecosystem. A pronounced differentiation in water consumption was identified during a drought period compared to other periods. SFD and canopy stomatal conductance decreased during drought period (Figs. 2 and 5). Results showed that the stand transpiration correlated significantly with VPD and RR. Critically low soil water supplies reduce tree water use and influence sap flux densities with increasing VPD and RR (Fig. 5). Low SWCs resulted in increased stomatal sensitivity to increasing VPD. The influence of VPD on Gs was dominant over that of SWC and RR (Fig. 7). SWC had no control on Gs during the dry period when VPD was high. Perhaps Q. serrata was more sensitive to VPD so that Gs did not depend on SWC during the drought period, even though SFD showed a linear relationship with SWC $(<35 \%)$. The interference of VPD suppresses the control of SWC on Gs. It was shown that VPD induced a reduction in Gs with decreasing SWC $(<35 \%)$ in Q. serrata. It was also observed that drought induced a reduction in transpiration. The stand transpiration in the analyzed drought period of 22 days was $15 \%$ of the total transpiration. Although the main driving factors were VPD and $\mathrm{RR}$, the transpiration rate of the investigated Q. serrata was slightly reduced by a decrease in SWC. We concluded that the drought exerted no damage on the tested tree species. This is however limited by using only one growing season (2007) data, without replicate analysis on the effect of drought on tree water use using multi-year field 
observation. A further study is therefore necessary to fully elucidate the mechanisms through which drought affects tree sap flow and stand transpiration.

\section{ACKNOWLEDGMENTS}

This study was supported by "Long-Term Monitoring and Assessment of Climate Change Impacts on Forest Ecosystem" project of Korea Forest Research Institute (KFRI).

\section{LITERATURE CITED}

Bovard BD, Curtis PS, Vogel CS, Su HB, Schmid HP. 2005. Environmental controls on sap flow in a northern hardwood forest. Tree Physiol 25: 31-38.

Bréda N, Cochard H, Dreyer E, Granier A. 1993. Water transfer in a mature oak stand (Quercus petraea)-seasonal evolution and effects of a severe drought. Can J For Res 23: 1136-1143.

Cienciala E, Kucera J, Malmer A. 2000. Tree sap flow and stand transpiration of two Acacia mangium plantations in Sabah, Borneo. J Hydrol 236: 109-120.

Cienciala E, Lindroth A. 1995. Gas exchange and sap flow measurements of Salix viminalis trees in short-rotation forest. II. Diurnal and seasonal variations of stomatal response and water use efficiency. Trees 9: 295-301.

Clearwater MJ, Meinzer FC, Andrade JL, Goldstein G, Holbrook NM. 1999. Potential errors in measurement of nonuniform sap flow using heat dissipation probes. Tree Physiol 19: 681-687.

Cochard H, Bréda N, Granier A. 1996. Whole tree hydraulic conductance and water loss regulation in Quercus during drought: evidence for stomatal control of embolism? Ann For Sci 53: 197-206.

Dierick D, Hölscher D. 2009. Species-specific tree water use characteristics in rainforestation stands in the Philippines. Agric For Meteorol 149: 1317-1326.

Epron D, Dreyer E. 1993. Long-term effects of drought on photosynthesis of adult oak trees Quercus petraea (matt) Liebl. and Quercus robur L. in a natural stand. New Phytol 125: 381-389.

Ford CR, Hubbard RM, Kloeppel BD, Vose JM. 2007. A comparison of sap flux-based evapotranspiration estimates with catchment-scale water balance. Agric For Meteorol 145: 176-185.

Garnier E, Berger A. 1987. The influence of drought on stomatal conductance and water potential of peach trees growing in the field. Sci Hortic 32: 249-263.

Goulden ML, Field CB. 1994. Three methods for monitoring the gas exchange of individual tree canopies: ventilatedchamber, sap-flow, and Penman-Monteith measurements on evergreen oaks. Funct Ecol 8: 125-135.

Granier A. 1985. Une nouvelle méthode pour la mesure du flux de sève brute dans le tronc des arbres. Ann Sci For 42: 193-200.

Granier A. 1987. Evaluation of transpiration in a Douglas-fir stand by means of sap flow measurements. Tree Physiol 3: 309-319.

Granier A, Biron P, Köstner B, Gay LW, Najjar G. 1996. Comparisons of xylem sap flow and water vapor flux at the stand level and derivation of canopy conductance for Scots pine. Theor Appl Climatol 53: 115-122.

Granier A, Bréda N. 1996. Modelling canopy conductance and stand transpiration of an oak forest from sap flow measurements. Ann For Sci 53: 537-546.

Granier A, Loustau D. 1994. Measuring and modeling the transpiration of a maritime pine canopy from sap-flow data. Agric For Meteorol 71: 61-81.

Granier A, Loustau D, Bréda N. 2000. A generic model of forest canopy conductance dependent on climate, soil water availability and leaf area index. Ann For Sci 57: 755-765.

Hinckley TM, Lassoie JP, Running SW. 1978. Temporal and spatial variations in water status of forest trees. For Sci 24: 1-72.

Hinckley TM, Teskey RO, Duhme F, Richter H. 1981. Temperate hardwood forests. In: Water Deficits and Plant Growth. Vol. 6 (Kozlowski TT, ed). Academic Press, New York, pp 153-208.

Hogg EH, Black TA, G den Hartog F, Neumann HH, Zimmermann R, Hurdle PA, Blanken PD, Nesic Z, Yang PC, Staebler RM, McDonald KC, Oren R. 1997. A comparison of sap flow and eddy fluxes of water vapor from a boreal deciduous forest. J Geophys Res 102: 28929-28937.

Hwang T, Kang S, Kim J, Kim Y, Lee D, Band L. 2008. Evaluating drought effect on MODIS Gross Primary Production (GPP) with an eco-hydrological model in the mountainous forest, East Asia. Glob Chang Biol 14: 1037-1056.

Idso SB, Kimball BA, Mauney JR. 1987. Atmospheric carbon dioxide enrichment effects on cotton midday foliage temperature: implications for plant water use and crop yield. Agron J 79: 667-672.

Irvine J, Perks MP, Magnani F, Grace J. 1998. The response of Pinus sylvestris to drought: stomatal control of transpiration and hydraulic conductance. Tree Physiol 18: 393-402.

Jarvis PG. 1976. The interpretation of the variations in leaf 
water potential and stomatal conductance found in canopies in the field. Philos Trans R Soc Lond B 273: 593-610.

Jung EY, Otieno D, Lee B, Lim JH, Kang SK, Schmidt MWT, Tenhunen J. 2011. Up-scaling to stand transpiration of an Asian temperature mixed-deciduous forest from single tree sapflow measurements. Plant Ecol 212: 383-395.

Kelliher FM, Leuning R, Raupach MR, Schulze ED. 1995. Maximum conductances for evaporation from global vegetation types. Agric For Meteorol 73: 1-16.

Kellomäki S, Wang KY. 1996. Photosynthetic responses to needle water potentials in Scots pine after a four-year exposure to elevated $\mathrm{CO}_{2}$ and temperature. Tree Physiol 16: 765-772.

Kellomäki S, Wang KY. 1997. Effects of long-term $\mathrm{CO}_{2}$ and temperature elevation on crown nitrogen distribution and daily photosynthetic performance on Scots pine. For Ecol Manag 99: 309-326.

Kellomäki S, Wang KY. 2001. Growth and resource use of birch seedlings under elevated carbon dioxide and temperature. Ann Bot 87: 669-682.

Köstner B, Granier A, Cermák J. 1998. Sapflow measurements in forest stands: methods and uncertainties. Ann Sci For 55: 13-27.

Köstner BMM, Schulze ED, Kelliher FM, Hollinger DY, Byers JN, Hunt JE, McSeveny TM, Meserth R, Weir PL. 1992. Transpiration and canopy conductance in a pristine broad-leaved forest of Nothofagus: an analysis of xylem sap flow and eddy correlation measurements. Oecologia 91:350-359.

Kumagai T, Aoki S, Shimizu T, Otsuki K. 2007. Sap flow estimates of stand transpiration at two slope positions in a Japanese cedar forest watershed. Tree Physiol 27: 161168.

Landsberg JJ, Gower ST. 1997. Applications of Physiological Ecology to Forest Management. Academic Press, Inc., San Diego, CA.

Lee D, Kim J, Kim SJ, Moon SK, Lee J, Lim JH, Son Y, Kang S, Kim S, Kim K, Woo N, Lee B, Kim S. 2007. Lessons from cross-scale studies of water and carbon cycles in the Gwangneung Forest catchment in a complex landscape of monsoon Korea. Korean J Agric For Meteorol 9: 149160.

Leuzinger S, Zotz G, Asshof R, Körner C. 2005. Responses of deciduous forest trees to severe drought in Central Europe. Tree Physiol 25: 641-650.

Liu X, Zhao P, Rao X, Ma L, Cai X, Zeng X. 2008. Response of canopy stomatal conductance of Acacia mangium forest to environmental driving factors. Front For China 3: 64-71.
Meinzer FC, Goldstein G, Holbrook NM, Jackson P, Cavelier J. 1993. Stomatal and environmental control of transpiration in a lowland tropical forest tree. Plant Cell Environ 16: 439-436.

Monteith JL. 1995. A reinterpretation of stomatal responses to humidity. Plant Cell Environ 18: 357-364.

Mott KA, Parkhurst DF. 1991. Stomatal responses to humidity in air and helox. Plant Cell Environ 14: 509-515.

Murray FW. 1967. On the computation of saturation vapor pressure. J Appl Meteorol 6: 203-204.

Nardini A, Pitt F. 1999. Drought resistance of Quercus pubescens as a function of root hydraulic conductance, xylem embolism and hydraulic architecture. New Phytol 143: 485-493.

O'Grady AP, Worledge D, Battaglia M. 2008. Constraints on transpiration of Eucalyptus globulus in southern Tasmania, Australia. Agric For Meteorol 148: 453-465.

Oren R, Pataki DE. 2001. Transpiration in response to variation in microclimate and soil moisture in southeastern deciduous forests. Oecologia 127: 549-559.

Oren R, Phillips N, Katul G, Ewers BE, Pataki DE. 1998. Scaling xylem sap flux and soil water balance and calculating variance: a method for partitioning water flux in forests. Ann For Sci 55: 191-216.

Pataki DE, Oren R. 2003. Species differences in stomatal control of water loss at the canopy scale in a mature bottomland deciduous forest. Adv Water Res 26: 1267-1278.

Pataki DE, Oren R, Phillips N. 1998. Responses of sap flux and stomatal conductance of Pinus taeda L. to stepwise reductions in leaf area. J Exp Bot 49: 871-878.

Pereira JS, Chaves MM, Caldeira, MC, Correia AV. 2006. Water availability and productivity. In: Plant Growth and Climate Change (Morrison JIL, Morecroft MD, eds). Blackwell Publishers, London, pp 118-145.

Roberts S, Vertessy R, Grayson R. 2001. Transpiration from Eucalyptus sieberi ( L. Johnson) forests of different age. For Ecol Manag 143: 153-161.

Sandford AP, Jarvis PG. 1986. Stomatal responses to humidity in selected conifers. Tree Physiol 2: 89-103.

Sevanto S, Nikinmaa E, Riikoner A, Daley M, Pettijohn JC, Mikkelsen TN, Phillips N, Holbrook NM. 2008. Linking xylem diameter variations with sap flow measurements. Plant Soil 305: 77-90.

Shin JH. 2002. Ecosystem Geography of Korea: Ecology of Korea. Bumboo Publishing Co., Seoul.

Sperry JS, Hacke UG, Oren R, Comstock JP. 2002. Water deficits and hydraulic limits to leaf water supply. Plant Cell Environ 25: 251-263.

Sperry JS, Pockman WT. 1993. Limitation of transpiration by hydraulic conductance and xylem cavitation in Betula 
occidentalis. Plant Cell Environ 16: 279-287.

Tan CS, Black TA, Nnyamah JU. 1978. A simple diffusion model of transpiration applied to a thinned Douglas-fir stand. Ecology 59: 1221-1229.

Tardieu F, Zhang J, Katerji N, Bethenod O, Palmer S, Davies WJ. 1992. Xylem ABA controls the stomatal conductance of field-grown maize subjected to soil compaction or soil drying. Plant Cell Environ 15: 193-197.

Valentini R, Mugnozza GES, Ehleringer JR. 1992. Hydrogen and carbon isotope ratios of selected species of a Mediterranean macchia ecosystem. Funct Ecol 6: 627-631.

Vertessy RA, Benyon RG, O’sullivan SK, Gribben PR. 1995. Relationships between stem diameter, sapwood area, leaf area and transpiration in a young mountain ash forest. Tree Physiol 15: 559-567.

Wang KY, Kellomäki, Zha T, Peltola H. 2005. Annual and seasonal variation of sap flow and conductance of pine trees grown in elevated carbon dioxide and tempera- ture. J Exp Bot 56: 155-165.

Wartinger A, Heilmeier H, Hartung W, Schulze ED. 1990. Daily and seasonal courses of leaf conductance and abscisic acid in the xylem sap of almond trees [Prunus dulcis (Miller) D. A. Webb] under desert conditions. New Phytol 116: 581-587.

Whitehead D. 1998. Regulation of stomatal conductance and transpiration in forest canopies. Tree Physiol 18: 633644.

Wilson KB, Hanson PJ, Mulholland PJ, Baldocchi DD, Wullschleger SD. 2001. A comparison of methods for determining forest evapotranspiration and its components: sap-flow, soil water budget, eddy covariance and catchment water balance. Agric For Meteorol 106: 153-168.

Wullschleger SD, Hanson PJ, Todd DE. 2001. Transpiration from a multispecies deciduous forest as estimated by xylem sap flow techniques. For Ecol Manag 143: 205213. 